\title{
Quality Improvement of Contextual Accounting Learning Management Based on Lesson Study in Senior High School
}

\author{
Suyatmini $^{1 *}$, Sutama $^{2}$, Wafrotur Rohmah ${ }^{3}$, Titik Asmawati ${ }^{4}$ \\ ${ }^{1,2,3,4}$ Universitas Muhammadiyah Surakarta, Surakarta, Indonesia \\ *Corresponding author.Email: suy276@ums.ac.id
}

\begin{abstract}
The objective of this study is to analyze and describe the quality improvement of contextual accounting learning management based on lesson study in senior high school of Surakarta. This is a qualitative study. The subjects of the study were principal, teachers, and students. The data was collected through observation, interview, and documentation methods. The data analysis technique was using interactive analysis including data reduction, data presentation, and drawing the conclusion. The result of this study shows that the contextual accounting learning management improves the quality of learning. It can be seen from several aspects: contextual learning strategy can motivate the students to comprehend the meaning of the learning material by associating it with their daily lives. By using this concept, it is expected that the learning outcomes are more meaningful to the students. The management of learning materials in accounting considers the urgency, complexity, and deep understanding of the materials. The learning materials delivered by accounting teacher was in accordance with the syllabus and lesson plan developed based on the determined basic competencies. The management of learning interaction makes a quality and varied learning process. The setting of reciprocal relationship between teacher and students, as well as among students are performed optimally through many activities in order to achieve the learning objectives.
\end{abstract}

Keywords: quality, management, learning, accounting, contextual, lesson study

\section{INTRODUCTION}

Discussing the quality of learning is always interesting from time to time. The low quality of education are debatable by many parties. Teachers interacting directly with the students is often considered as the cause of low quality of education, which eventually returns to teacher training institute (LPTK) as the responsible institute. Actually, the problems of education quality is not as simple as it is. Many factors affecting the education quality, starting from the curriculum, school facilities, parents and the relevant institutions which form a unity in a system. This system must run effectively and always form an interaction between the components within.

According to Purwanto [9], the quality of learning can be seen from the process and learning outcomes. From the process, a learning is said to be qualified if all or at least $(75 \%)$ of the learners are actively involved in physical, emotional and social of the learning process besides demonstrating enthusiasm in learning. While from the outcomes, the learning process is said to be successful if there are positive changes in all learners of at least $(75 \%)$ of them. Furthermore, learning process is said to be successful and qualified if the input is even, producing a lot and high quality outcomes, as well as in line with the demand, growth of society and development.

"Learning quality can be improved by developing the emotional quotient, for intelligence only cannot generate a whole human being, as expected by the national education." [7]. Through emotional quotient, it is expected that all elements involved in education and learning can help the students to better understand themselves and environment, to be confident, not being jealous, envy, afraid, gloomy, despair, and ill-tempered. Mulyasa [7] adds that there are some methods to develop emotional quotient in learning, such as: 1. Providing a conducive environment. 2. 
Creating a democratic learning climate. 3. Developing empathy, and feel what the learners are feeling. 4. Assisting the learners in finding the solutions to their problems. 5. Optimally involving the learners to participate in the learning process physically, socially, and emotionally. 6 . Positively responding to every behavior of the learners and avoiding negative responses. 7 . Becoming the role model in enforcing the rules and discipline in learning.

It is in contrast with Sudjana [10] who says that learning quality is the effectiveness level of learning process in achieving learning objectives. The main objective of learning process is achieving the formulated objectives. Learning quality is needed to achieve the learning objectives, meaning that to get the optimum outcomes, the teacher should optimally utilize the components of learning process. Therefore, a quality learning management can be conducted through developing the learning strategy management, learning materials management, as well the learning interaction.

\section{BACKGROUND}

Accounting learning approach at senior High School in Surakarta much of it is teacher centered. This is called a teaching activity. Teacher dominance in teaching can result in learning communication ineffective accounting

The problem that needs to be resolved immediately is the ability of the Surakarta City Senior High School Accounting teachers to improve the quality of contextual Accounting learning management based on lesson study.

\section{METHODS}

This is a qualitative study. According to Sutama [11], qualitative research puts emphasis on understanding and meaning, is closely related to certain values, emphasizes process rather than measurement, describes, interprets, and gives meaning and is not enough with mere explanation, and utilizes multi methods in research. The research location is in Senior High School at Surakarta City. The subjects of the study were principal, accounting teachers, and students. The data was collected through observation, interview, and documentation methods. The data analysis technique was using the interactive analysis including data reduction, data presentation, and drawing the conclusion [6]. Data validity uses triangulation method and sources.

\section{RESULT AND DISCUSSION}

Improving the quality of accounting learning can be seen from the effectiveness level of the learning process in achieving the formulated learning objectives, including the learning strategy, learning material management, and learning interaction.

\subsection{Contextual accounting learning strategy}

Contextual leaning strategy is a holistic education process aiming at motivating the students to comprehend the meaning of the learning materials by associating it with their daily live context. Therefore, the students will have the knowledge/competence that can be applied into a problem to another. Contextual approach is a learning concept that helps the teacher to associate the teaching materials with the actual condition of the students as well as encouraging them to correlate their knowledge with its implementation in their daily lives as the member of family and society. By using this concept, it is expected that the learning outcomes are more meaningful to the students. The learning process runs naturally with students practicing and experiencing, instead of transferring the knowledge from the teacher to the students. The teachers are responsible for assisting the students to reach their goals. Their duty is managing the class working together as a team to find new experiences to the students.

There are eight components in contextual learning that are: (1) creating meaningful correlations, (2) doing meaningful activities, (3) performing independent learning, (4) cooperating, (5) creative and critical thinking, (6) helping individual to grow and develop, (7) achieving a high standard, and (8) using an authentic assessment [3]. Accounting learning with contextual strategy is the best to implement in accounting learning process, for it allows the knowledge and information to be embedded into the students' memory. However, in its implementation, the teachers often face some problems.

The problems faced by the teachers in implementing contextual accounting learning are: (a) it is hard to formulate the learning scenario or lesson plan for each stage of students' activities, (b) poor understanding in how to correlate the learning materials with the actual condition of the students or the existing knowledge, (c) insufficient materials and students' abilities. Consequently, the learning process will be hindered since the students are not ready yet, and (d) using computer and LCD as the learning media is not enough. The teachers know the importance of using the media in accounting learning process. The media in accounting learning process is useful for: (1) helping the students to better understand the materials, (2) senior high school students need real media, and (3) accelerating understanding the concept. Those problems can be solved by activating the teacher working group (MGMP) in the Regency/City. The activities of MGMP can be used to solve the problems faced by the teachers in delivering the materials to the students.

\subsection{Teaching material management in accounting learning}

Teacher activities in preparing learning materials is referring to the basic competencies and standard competencies contained in the syllabus. Developing syllabus in the lesson plan for social science class, particularly in accounting lesson, the teacher uses it as formulated in the lesson plan since a teacher must have plans in conducting the teaching and learning process. If a teacher does not prepare the lesson plan, the teaching and learning activities will not run smoothly and might create a gap in the class. Lesson plan preparation must be developed in accordance with the syllabus and curriculum. The teaching material management should follow the plan in order to achieve the learning 
objectives as well as the minimum mastery criteria (KKM) set by the school.

Urgency, complexity, and deep understanding of the materials should be considered to achieve a quality teaching material management. The teaching materials or sources used by the teachers in a quality learning must be varied from the environment as the learning sources also use the Internet. Teachers must master the accounting materials since it involves calculation for the transactions to be recorded into financial statements. It allows the students to think creatively, be skillful, and knowledgeable in the working world, especially in accounting.

The Curriculum of Senior High School in Surakarta is still using two curricula which are KTSP (school-based curriculum) and 2013 Curriculum. It is relevant with Kirkham [4] who said that curriculum approach could improve an effective learning and broaden students' experience to understand accounting as based on the curriculum. It is a good approach for the students to learn accounting. It means that curriculum approach to improve the learning experience in accounting is related to the improvement of students' achievements.

The material completion for the students is started from the simple to the complex one, such as doing accounting journal, general ledger, subsidiary ledger, and worksheet then translated into financial statements. Accounting requires high accuracy and analysis in recording, starting from analyzing the transaction evidence to the existing journals in the materials. Accounting deals with analysis, interpretation of transaction to be recorded in accordance with the principle of recognition and measurement from each concept of financial statement elements in one accounting period. During the accounting learning process, the students practice accounting to determine the profit and loss rate of a company.

The teacher should utilize the handbooks including: (a) printed materials, (b) audio materials, (c) visual materials, and (d) interactive materials so the teacher can teach in accordance with the specific criteria and handbook that are in accordance with the curriculum [5]. Overall, the teaching material management in senior high school of Surakarta is inadequate. Therefore, improving teachers' creativity is required so that the students enjoy learning accounting and make them satisfied with the teaching material management in the class. The main goal of teaching is learning materials, while the successful learning is measured from students' mastery on the lesson delivered by the teacher. The learning material itself is the knowledge from lessons taught at school. The learning material is the past experiences arranged systematically and logical which then described into handbooks in which the content must be mastered by the students [2]. In sum, the teachers are responsible for delivering the materials so that the students will understand and master the accounting materials as formulated in the book, particularly in accounting lesson. The teacher should be able to transfer the knowledge, so the senior high school students in Surakarta can understand and master the accounting materials and lesson as expected by the accounting teacher.

Accounting is a teaching material that cannot be changed since it is a part of the learning set for social science class. Not only the accounting learning that must be improved, but also the teaching. It is relevant to Vincent [12] who stated that accounting should not only be taught at top schools but also at other schools since accounting is a general lesson. A suitable and comprehensive accounting learning will absolutely improve students' knowledge.

\subsection{Management of Quality Accounting Learning Interaction}

Accounting learning interaction happens between the students and the teacher, among the students, as well as the teacher and students. Interaction in learning takes place at the initial stage of learning, during the learning activities, and at the end of learning process. Teacher as the facilitator has an important role in encouraging conducive interaction in a quality learning process. By using the contextual method, the students can become more confident in carrying out accounting learning activities while having in-depth understanding in accounting report. The ability to ask questions, respond, and manage problems are significant competencies in improving a quality learning interaction.

The contextual accounting learning does not emphasize only on knowledge, but also on developing attitude and skills. It proves that accounting learning in senior high school of Surakarta is qualified, where the students become active, creative, innovative, and having good skills. Dallimore [1] suggests that cooperative learning provides the students with enjoyment in learning accounting since it allows class discussion and pair discussion. Teaching should be conducted in such a way to accommodate students' learning styles and the method for a better accounting ethics. Teacher should know whether the students are ready to learn or not [8]. Furthermore, the impact of interaction is supported by students' subjectivity on the interaction, teaching method, and learning styles. If the students are passive, the teacher should be able to encourage their confidence. Confidence affects the problem-solving skill of the students. The students who are positive perform better in problem-solving or in other words, they have positive attitude in learning.

\section{CONCLUSION}

The management of contextual accounting learning strategy motivates the students to understand the meaning of the materials by associating it with their daily live context. Contextual approach is a learning concept that helps the teacher to associate the teaching materials with the actual condition of the students as well as encouraging them to correlate their knowledge with its implementation in their daily lives as the member of family and society. By using this concept, it is expected that the learning outcomes are more meaningful to the students.

The management of teaching materials in accounting for a quality learning need to consider the urgency, complexity, and deeper understanding of the materials. These are important to deliver meaningful materials to the students. Teacher tends to complete the teaching materials without paying attention to the urgency, complexity, and deeper understanding of the materials. The learning materials delivered by accounting teacher was in accordance with the syllabus and lesson plan developed based on the determined basic competencies. 
Interaction management is an optimal reciprocal setting between the teacher and the students, as well as among students. This interaction management allows the quality and varied learning processes. If the teacher is able to create a good interaction, the learning implementation will be better. On the other hand, if the teacher cannot create a good class interaction, the learning outcomes in accounting will not be maximal.

\section{REFERENCES}

[1] Dallimore, Elice. J. Hertenstein Julie H. dan Platt Majorie B. 2010 Issues In Accounting Education. Class Participation in Accounting Courses: Factors

[2] Hamruni. 2012. Strategi Pembelajaran, Yogyakarta: Insan Madani.

[3] Jonhson, Elaine B. 2009. Contextual Teaching and Learning, (Terjemahan Ibnu Setiawan, Cetakan VII). Bandung: Mizan Learning Center.

[4] Kirkham, Ross. 2013. An Approach to Improving the Learning Experience for First Year Accounting Currriculum University of the Sunshine Coast, Australia. EJournal of Business Education \& Scholarship of Teaching. 7 (1). 2013, pp.7481.

[5] Majid, Abdul.2012 Perencanaan Pembelajaran Mengembangkan Standar Potensi Guru, Bandung: PT. Remaja Rosdakarya.
[6] Miles, Matthew B. dan A. Michael Huberman. 2007. Analisis Data Kualitatif. Terjemahan Tjetjep Rohendi. Jakarta: Penerbit Universitas Indonesia.

[7] Mulyasa. 2006. Kurikulum Berbasis Kompetensi, Bandung: PT. Remaja Rosdakarya.

[8] O'Leary, Conor dan Stewart Jenny, 2012. J Bus Etthics Accounting and Law Discipline, Griffith Business School.The Interaction of Learning Styles and teaching Methodologiesin Accounting Ethical Introction, Nathan Campus, Griffith University, 170 Kessels Road, Nathan, dan Griffith University, Logan Campus, Logan Australia 113: 225-241.

[9] Purwanto, Ngalim, 2004. Psikologi Pendidikan, Bandung: Remaja Rosdakarya.

[10] Sudjana, Nana, 2004. Dasar Dasar Proses Belajar Mengajar, Bandung: Snar Baru Algensindo.

[11] Sutama. 2012. Metode Penelitian pendidikan (Kuantitatif, Kualitatif, PTK, $R \& D$ ) Gumpang Kartasura: Fairus Media.

[12] Vincent.2012. Using Learning Study TO Improve The Teaching And Learning Of Accounting In A School In Brunei Darussalam, International Journal For Lesson And Learning Studies, Vol.1 No.1 2012.pp23-40. 